\title{
Ensuring Public Order during the Court Hearings in the Context of Reforming the Judicial System of Ukraine
}

\author{
Забезпечення правопорядку під час судового засідання в умовах реформування \\ судової системи України
}

Received: May 18, 2020

Abstract

The relevance of the issue raised in the article is due to the fact that one of the key aspects of reforming the judicial system in Ukraine, which must meet European standards, is to ensure public order during the court hearing. In this regard, the subject matter of the article is the world-tested methods and ways of ensuring public order during the court hearing. While writing the article the authors have used the following methods: formal and legal, analytical, system analysis, system and structural. The problems that currently exist and are in the way of effective development of the national judicial system of Ukraine have been analyzed. While analyzing the most problematic and relevant issues of ensuring public order in courts the authors have emphasized on the intensification of tendencies to strengthen the security of the subjects participating in the court hearing. At the same time, it has been stated that there is the spread of the policy of many states for increasing the level of democratization of the judicial process, in particular by granting wider rights and freedoms to all its participants. Based on the successful experience of foreign countries, the authors have suggested the ways to improve the judicial process in Ukraine in the whole and not just to ensure public order during the court hearing. Special attention has been paid to the Judicial Protection Service. It has been determined that the improvement of the national legislation of Ukraine
Accepted: July 26, 2020

Written by:

Maryna Vyacheslavivna Dzhafarova ${ }^{1}$ https://orcid.org/0000-0002-2831-7371

Hanna Sergiivna Ivanova ${ }^{2}$ https://orcid.org/0000-0002-2658-3502

Svitlana Zahorodniuk ${ }^{3}$ https://orcid.org/0000-0003-0108-6953

Uliana Olehivna Zaiets https://orcid.org/0000-0002-1013-5270

\footnotetext{
${ }^{1}$ Doctor of Jurisprudence, Associate Professor, Professor of the Department of Administrative Law and Procedure of the Faculty № 1 of Kharkiv National University of Internal Affairs.

${ }^{2} \mathrm{PhD}$ in Law, Doctoral Candidate of the Department of Administrative Law and Administrative Activities of Yaroslav Mudryi National Law University.

${ }^{3}$ Candidate of Law, Associate Professor, Odessa State University of Internal Affairs.

${ }^{4}$ Adjunct of Educational and Scientific Training Organization Department of Kharkiv National University of Internal Affairs.
} 


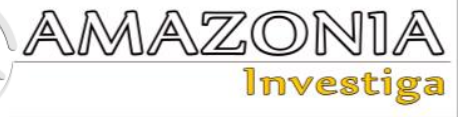

on ensuring public order during the court hearing should take into account both national traditions of judicial proceedings and European standards. At the same time, the implementation of international standards in these areas should be systematic and comprehensive. In this regard, it is necessary to form a single concept in this area. The conclusions have offered three main interrelated stages of improvement of the legislation of Ukraine in terms of ensuring public order during the court hearing.

Key words: court hearing, public order, court process, protection of public order, protection of subjects, ensuring public order, innovative methods, security of persons, quality process.

Окрему увагу приділено Службі судовій охороні. Визначено, що удосконалення національного законодавства стосовно забезпечення правопорядку під час судового засідання має відбуватися з урахуванням як вітчизняних традицій здійснення судочинства, так і європейських стандартів. При цьому імплементація міжнародних стандартів у даній сфері має відбуватися системно й комплексно, у зв'язку з цим необхідно сформувати єдину концепцію 3 цього напряму. У висновках запропоновані три основні взаємопов'язуючі етапи удосконалення законодавствам України в частині забезпечення правопорядку під час судового засідання.

Ключові слова: судове засідання, правопорядок, судовий процес, охорона правопорядку, захист суб'єктів, забезпечення правопорядку, інноваційні методи, безпека осіб, якісний процес.

\section{Introduction}

The European Convention through Article 6 establishes a fundamental principle for a democratic society and a rule of law. The right to a fair trial is applicable both in civil matters and in criminal matters, where the rights, freedoms and legitimate interests of the justiciable must be guaranteed. This right must be respected by all the judicial bodies, because by violating it or ignoring it, serious damages can be brought about the person's freedom, access to justice, equality of arms, the right not to incriminate s.a.m.d. Precisely for its importance, the right to a fair trial is considered as a pillar of support for the democratic state (Silviu-Ștefan, 2019).

In the world legal science, a systematic approach to the study of judicial law issues is formed within the framework of the regulatory theory (the concept of a "regulated judge") and is used for the construction of the model of the future court in view of the development of information technologies and artificial intelligence. International organizations actively use the methodology of judicial law as an indicator of the effectiveness of the judicial system (Chechulina, 2020).

The issue of reforming the judicial system in modern Ukraine is one of the most controversial issues for the improvement of the national legal system, as well as the further development of Ukraine as a democratic, social, legal state. Security of the trial in this process is one of the most important factors in the successful

existence and development of social relations that arise in court. It is explained by the fact that the proper protection of the rights and freedoms of everyone, without exception, the subjects of the judicial process is the mandatory requirement without which the independence and impartiality of the judicial system would be impossible.

In general, the example of the historical development of society can clearly demonstrate that the need to provide both judges and other participants in the proceedings has always existed in one way or another. Although the parties of defense and prosecution, as well as third parties (such as witnesses and experts), often had different statuses and different names for their professions depending on their particular historical era and state, they always found a consensus among society regarding their personal protection. Experts emphasize that proper observance of public order in the courtroom during any proceedings is the main condition for quality and impartial administration of justice.

Nowadays, the Decree of the President of Ukraine "On the Strategy of Sustainable Development" "Ukraine 2020"” (2015) is important. It outlines the reform plans not only within the judicial system, but also in other areas. The purpose of reforming the judicial system is to reform the judiciary and related legal institutions in order to put into practice the principles of the rule of law and to ensure that 
everyone has the right to a fair trial by an independent and impartial tribunal. The reform should ensure the functioning of the judicial power, which meets the urgent public expectations of an independent and fair court, as well as the European system of values and human rights standards. All this is within the framework of Ukraine's Euro-Atlantic integration. According to this Strategy the reform is carried out in two stages:

the first stage is immediate update of the legislation aimed at restoring confidence in the judicial power in Ukraine;

the second stage is systemic amendments in the legislation: a) adoption of the new Constitution of Ukraine and, on the basis of the corresponding constitutional changes; b) the adoption of new laws relating to the judiciary, other related legal institutions.

Taking into account the above facts, the purpose of this article is to determine the features of ensuring security and public order during the court hearings in the context of reforming the judicial system of Ukraine. Based on the successful experience of foreign countries, the authors have suggested the ways to improve the judicial process in Ukraine in regard to ensuring public order during the court hearing.

\section{Theoretical framework}

Proper compliance with security standards in national courts, as well as non-compliance with the current legislation of Ukraine on this issue have forced a large number of scholars and human rights experts to actively study this issue. In particular, it should be noted that many scholars in their works tried not only to study the formation and evolution of the judicial system and methods of ensuring public order in its functioning, but also to put forward their own ideas and views on possible ways of improving the security and public order in the courts. In this regard, it can be emphasized that society has the opportunity to carefully get aquinted with a large number of research papers on the above topics. The greatest relevance and authority have the scientific works and researches of such scholars as:

Andrusiak T. (the author's works investigate the historical aspects of the development of the judiciary, 2011, 2018);

Chechulina A. (the article is devoted to the analysis of approaches to understanding judicial law, 2020);
Kuzmenko V. A. (current problems of applying Removal from the Courtroom as a measure of Procedural Coercion in the Administrative Process are researched; different kinds of Removal as a measure of Coercion from other procedural actions are discovered; the bases for applying the removal in the administrative process are analyzed; the influence of the applying removal on the realization of principles of administrative process is determined; the term of applying the removal as the measure of procedural coercion is analyzed, 2013);

McKeever (research at Ulster University (preCovid-19) has been examining how LIPs participate in court processes, particularly in the court hearings, to help identify the points at which the LIP's right to effective participation under Article 6 ECHR could be at risk; the content is posted here to help identify the issues to be considered in evaluating how successful remote hearings might be in protecting the LIP's right to effective participation, 2020);

Ngari and Olojo (the study is dedicated Nigeria's criminal justice system is dealing with thousands of people in mass trials related to terrorism offences - including those committed by suspected Boko Haram members, 2020);

Panchenko O. (the article is devoted to characteristics of the usage of procedural compulsion in administrative proceedings in foreign countries (France, Germany, Poland, Kazakhstan, Belarus, the Russian Federation, Latvia, Estonia, the United States); the attendance of institutional and consolidated (at the level of an individual structural part of Procedural Code) approaches to the legislative consolidation of procedural compulsion in administrative proceedings considered foreign countries, 2008);

Pylypchuk O. O. (the formation of the socialpolitical system, the division of the Roman population into genuses and families, the formation of social classes of patricians, plebeians and proletarians, the centralization of power in the hands of an elected monarch, the administration of the state through the Senate, the formation of a troop divided into centuries, which subsequently turned into a separate social stratum that became representative of the interests of the people and had a tremendous impact on the state power of the country, 2018); Shabalin A. (the author examines the features of the formation and development of the institution of order production as an independent type of civil proceedings in the legislation of Western and Eastern Europe; on the basis of the above historical and legal analysis, proposals have been formulated to improve the procedure for issuing 


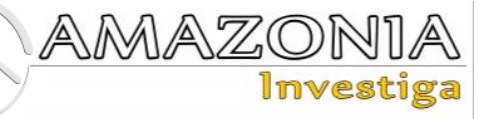

a court order in the civil process of Ukraine, 2010);

Silviu-Ștefan P. (examining norms the European Convention through Article 6 establishes a fundamental principle for a democratic society and a rule of law; the author noted that the right to a fair trial is applicable both in civil matters and in criminal matters, where the rights, freedoms and legitimate interests of the justiciable must be guaranteed, 2019);

Vatamaniuk L. (explores problematic issues of the practical implementation of the provisions of the national legislation on the judicial system and the status of judges (in the context of international legal standards), 2018).

The authors analyze the most authoritative works of national and foreign experts, as well as formulate their conclusions based on the successful experience of developed countries in ensuring order and security in the courts. In this regard, the problem of scientific and theoretical study of the organization and functioning of the basic institutions of a democratic state is an important urgent task of jurisprudence, especially its such branches as the theory of state and law, constitutional law, history of doctrines of state and law and corresponds the EuroAtlantic inspirations of Ukraine.

\section{Methodology}

Methods and techniques of scientific cognition, which are defined in accordance with the purpose of the study, constitute the methodological basis of the article. The work combines general scientific and special methods, which in complex application allowed to achieve positive research results.

Thus, the formal and legal method was used in the study of scientific sources focused on various issues of ensuring security and public order during the court hearings. In particular, the scientific works in which problems were studied were studied, issues related to the subject of this article.

The analytical method was used during the analysis and substantiation of some theoretical authors' positions, for example, the stages of improving the legislation of Ukraine on ensuring security during the court hearings.

Methods of system analysis, as well as system and structural were used in the analysis of legal regulation of the issue of ensuring security during the court hearings, in particular, the study of certain provisions of the Law of Ukraine "On
Judicial System and the Status of Judges", the Decree of the President of Ukraine "On Sustainable Development Strategy "Ukraine 2020 "', etc.

\section{Results and discussion}

Starting from the very beginning of the process of formation of social relations in the world, various conflicts and disputes have constantly arisen between their subjects. For their successful settlement, there was an urgent need for an independent third-party entity, preferably with imperative powers, to administer justice in resolving conflicts. This is how the first prototypes of courts in various countries of the Ancient World began to appear.

It should be noted that the first mention of judicial protection in Ukraine dates back to the Cossack era. Judges at that time did not need protection, because they did not decide anything personally, but made propositions for consideration by the whole society, which made the final decision. However, the general foreman (general judge) had a kind of protection - juries. Later, Demyan Mnohohrishnyi created the Hetman's Guard - a specific security service, a small military unit.

The Ukrainian people have always been a part of European civilization, were full-fledged and created and improved it until they were torn away from it. For example, Ukrainian Yosyp Levitsky was a judge of the Supreme Court of the AustroHungarian Empire. He worked for a long time in the judicial system and became a corrugator at the Supreme Tribunal in Vienna (Andrusiak, 2011; 2018).

It is clear that in order to effectively continue to ensure the objectivity and independence of the judicial institutions, they should be provided with appropriate security guarantees. It should be emphasized that such security guarantees concerned not only the physical protection of judges and other participants in the process, but also the protection of order during the hearings. Thus, we talk about the supervision over observance of all norms and procedures of carrying out court hearings by the competent representatives of the state endowed with the powers provided by the legislation.

The legal system of each state is exceptional, operates in specific historical circumstances and at a certain level of its socio-economic development. The integration of the national institution of justice into the European one, and 
hence the world legal space must be realized by initiating a single public order with obligatory consideration of national identity. It is constitutionally important to create an effective legal mechanism for correlating national legislation on the institution of justice in accordance with international standards (Vatamaniuk, 2018).

Harmonization of legislation is equivalent to a purposeful process of convergence, harmonization and interaction of national legal systems on the basis of common international legal standards declared within the relevant legal space, which aims to generalize legal requirements in certain countries, achievement of consensus legislation and compliance with European legislation and international requirements, elimination of legal conflicts by forming and approving a comprehensive legal policy, common legal principles, rules, legal standards for different legal systems, which provides coordinated activities of all subjects of the state, which is carried out carefully and consistently within their competence (Tykhomyrov, 1996).

Customary international laws are rules of law derived from consistent state practice, i.e. a widespread repetition of similar acts over time, and acting out of a sense of obligation (opinion juris). International humanitarian law (jus in bello), which regulates armed conflict, has long been recognised as a constituent part of customary international law. These have been codified in various international treaties including the 1949 Geneva Conventions and their Additional Protocols.27 All states are bound by customary international law (Ngari, Olojo, 2020).

The establishment of a transparent and fair system of supervision over the compliance with public order during court hearings, and the protection of the fundamental rights, freedoms and legitimate interests of all persons involved in the trial, was directly dependent on the level of democracy of a particular state. This statement in practice meant that in case of a true orientation of the government of a country to ensure the true rule of law, liberalism and the achievement of true justice in society (i.e. in social relations between individuals), such an orientation is instantly reflected in the order and procedure of conducting court hearings in such a state.

However, as we know from history, not all states supported the movement for the spread of freedom and equality among members of society.
Moreover, it should be noted that until recently, that is, for most of human history, inequality between subjects of legal relations was considered the norm and therefore dominated almost all over the world. Among the classic forms of such social inequality are slavery in all its forms, the policy of restricting the political rights of some people by their origin (Ancient Rome), skin color (USA in the past), period of residence (Russia), religion, and many other forms of discrimination.

Accordingly, the policy of maintaining inequality in public relations quickly shifted to litigation in such states. In general, it should be emphasized that those countries whose political leadership does not aim at the proper observance and protection of the rights and freedoms of every person and citizen as the highest value, but, on the contrary, prefers to achieve its power and any other goals. capacious rights of individuals to life, health, honor and dignity, the trial was often just a fiction (Pylypchuk, 2018).

For example, this state of affairs took place in the Ancient Rome. In the days of the republic, magistrate courts tended to support aristocrats, but still tried to administer true justice in disputes between the subjects of the legal system of that time. But when Julius Caesar took power and the subsequent transformation of the Roman Republic into the Roman Empire by his nephew Octavian Augustus, the Ancient Roman courts finally lost the remnants of their independence and impartiality, obediently following the instructions of the emperors. This historical case is characterized by the fact that it became the first well-documented precedent of abuse of power by the heads of state in order to subordinate state courts to their own will.

After that, "puppet" justice for the next centuries became one of the most characteristic features of an authoritarian or totalitarian country. Thus, the Ancient Rome, as well as all the despotic, oligarchic, and other authoritarian states that emerged after its fall, tended to use the country's judicial system for their own needs. As a rule, this was done in order to repress and eliminate political opponents and critics of the regime (Shabalin, 2010).

An adequate level of security in court, as well as ensuring the protection of the rights and freedoms of all participants in the trial, as well as ensuring the equality of the parties in court in authoritarian states, have never been truly observed and enforced. And that, in turn, is a complete evidence of the impossibility of an 


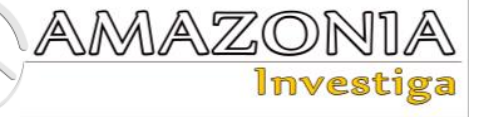

impartial and independent functioning of the judicial system in such states. Thus, summarizing this digression into the history of public relations, it can be noted that an effective system of public order during court hearings takes place only in those countries that meet high generally accepted standards of democracy and the rule of law (Criminal Procedural Code of Ukraine, 2012).

In addition to the above mentioned, it should be emphasized that the methods and means of proper protection of court hearings also find their progressive development in the most developed democratic countries. According to the information published in open scientific and statistical sources, it should be noted that the means of ensuring security and public order in the courts are constantly being improved. Among other things, it is noted that one of the most dynamic is the development of technical and technological equipment of security and protection.

Nowadays, security service experts are confident that the latest systems for supervising and monitoring security in courtrooms are extremely developed. Along with them, the means of search and scanning of persons and areas in locations important for law enforcement agencies have been widely improved. If we reveal this issue more specifically, it should be noted that the most serious assistance to law enforcement agencies is provided by such tools as state-of-the-art CCTV cameras, audio recording systems, photo-fixing devices, stationary and portable thermal imagers, authentication systems for their individual biological characteristics (finger prints, retina, sweating), etc. The active use of all these tools has made it much easier for law enforcement agencies to carry out their duties. First of all, to establish and record cases of violation of generally accepted security standards by persons during court hearings, to detect them in time, and, accordingly, to investigate them. The direct consequence of such a new reality will inevitably be an increased risk of being caught by those who commit or plan to commit such offenses. And this, in turn, will lead to a significant reduction in further violations of safety norms and standards during court hearings in the future (Tatsii, Hroshevyi, Kaplina, Shylo, 2013).

Considering the basic essence of this interconnected logical link of things that are directly dependent on each other, scholars have concluded that the key elements of ensuring public order within the judicial system should be new tactical methods and technological means of detecting violations and their active implementation. Moreover, according to the results of the latest research in the field of security and protection in state institutions and judicial authorities, the emphasis is on the timely introduction of the latest systems and devices for detecting and recording offenses into the daily work of security structures, as well as means of monitoring environment (particularly in and around the courtroom) is a powerful weapon in counteracting the dangers to public order.

At the same time, the introduction and further use of various ways to successfully counter modern threats to public security (including those that threaten the safe functioning of the judicial system), created on the basis of active use of the above high-tech devices and tools, is also effective. According to a number of experts, it is a clearly and qualitatively constructed structure of court protection as an object of protection, together with all participants involved, should be considered the most important component in compliance with security standards in courts (Panchenko, 2008).

First of all, we talk that effective security during a court hearing is impossible without the implementation of a proper system of methods and procedures - specific actions of persons who are specially endowed by the state with the powers necessary to protect court hearings. Another factor that could significantly reduce the level of wrongful acts committed from time to time by persons present at the court hearings would be the establishment of the system of irresponsible liability for persons for their actions.

It is a well-known fact that the understanding of individuals of the possibility of mandatory liability in case of committing crimes, offenses and any other actions, the implementation of which interferes with the normal conduct of the trial or even jeopardizes the functioning of the judicial agency, is a powerful deterrent for them. It should be separately added that such an institution of liability, established for each participant in the trial without exception, should operate only on the terms of individuality. It is necessary because even the same in content and essence illegal acts committed by different persons should be considered independently of each other. Because most often the crime in each case was caused by various factors, such as motivation of the person, his physical and mental condition and many other factors (Kuzmenko, 2013).

There were special police units within the Ministry of Internal Affairs in independent 
Ukraine from time to time, which were entrusted with the functions of protecting and ensuring the safety of court staff and trials. But after the creation of the National Police of Ukraine in 2015, these special units were disbanded.

One of the important elements of the judicial reform launched in 2014 is the creation of an agency tasked with ensuring public order in the judicial facilities, ending contempt of court, and protecting court premises and directly all court participants.

Recently, court landmines have become commonplace, with overly emotional visitors to the judicial facilities damaging the property or personal belongings of litigants, deliberately disrupting court hearings, and threatening their participants. That prompted the judicial power of Ukraine to create an independent state agency the Judicial Protection Service.

On April 4, 2019, the High Council of Justice by its Decision approved the Regulations on the Judicial Protection Service (High Council of Justice, 2019), and began the creation of this state agency with law enforcement functions.

The need to create this state agency is due to the fact that the Art. 160 of the Law of Ukraine "On the Judicial System and the Status of Judges" provides that keeping public order in court, cessation of contempt of court, as well as protection of court premises, agencies and institutions of justice, functions with regard to the state security of personal security of judges and members of their families, court employees, the security of court participants is ensured by the Judicial Protection Service.

The Judicial Security Service - is a state agency that through its units keeps public order in court; prevents manifestations of contempt of court and stops such manifestations; protects the premises and other property of courts, judicial authorities; provides state protection of judges, court staff and their families, as well as guarantees the safety of participants in court proceedings (the Art. 160 of the Law of Ukraine "On the Judicial System and the Status of Judges").

The Judicial Protection Service is accountable to the High Council of Justice and is under the control of the State Judicial Administration of Ukraine, and consists of the central governing agency (Central Office) and territorial subdivisions (territorial administrations) of the Service.
The central governing agency of the Service is a legal entity, has a seal with the image of the State Emblem of Ukraine and its name, its own forms, independent balance and accounts in the agencies of the State Treasury Service of Ukraine. Territorial departments of the Service are formed as legal entities, have a seal with the image of the State Emblem of Ukraine and its name, own forms, independent balance and accounts in the agencies of the State Treasury Service of Ukraine.

It is planned that in 2020 more than 400 institutions of the Ukrainian justice system will be under the protection of the Service, and by the end of 2021 - 855 of them, and will be completely released from their functions of the National Police and the National Guard of Ukraine. The maximum number of employees of the Service at the end of 2021 is planned at 14 thousand people.

\section{Conclusions}

The establishment and successful functioning of the system of ensuring public order during the court hearings is possible only when several important components are observed at the appropriate level. These include effective methods and ways of detecting offenses during the court hearings, as well as successful counteraction to such phenomena. In addition, according to the experience of developed countries, a clear and understandable system of inevitable liability of offenders should be established.

In our opinion, the improvement of legislation in terms of ensuring public order during the court hearings should take place in stages:

first of all, it is the formation of a national concept (program) of bringing the legislation of Ukraine in line with international standards (to identify the range of problematic issues and to outline possible ways of their legal settlement); secondly, to conduct a legal examination of the provisions of national legislation for their compliance with international standards; thirdly, making amendments and alterations to the current legislation, without violating the national legal judicial system.

For example, the Nuffield Foundation has now provided additional funding (2019-2022) to address the findings and recommendations of the original research, specifically on how to identify and manage the participative barriers to reduce the risk of a breach of article 6 ECHR. There are 


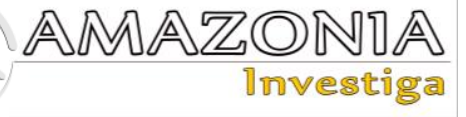

two elements to this current research project. First, the creation of support materials for LIPs, based on a human-centred design process that works with a large group of stakeholders, including LIPs.5 The materials proposed by the group are currently being prototyped by the research team, to be tested with LIPs in family courts in Northern Ireland. Second, using data from the first LIP project to develop a checklist of legal participation, to be tested and refined through court observations and interviews (McKeever, 2020).

\section{Bibliographic references}

Andrusiak, T. (2011). Ukrainian Judges of the Austro-Hungarian Empire and Their Contribution to the Development of Ukrainian Legal Thought. Judicial power in Ukraine and the world: history, modernity, development perspectives: materials of the XXV International Historical and Legal Conference in Saki. Pp.112-119.

Andrusiak, T. (2018). Ukrainian Judges in the Activities of Taras Shevchenko Scientific Society as an Illustration of the Distribution of Power in the Austro-Hungarian Empire. Judicial power in Ukraine and other countries: history and modernity (aspects of law): Materials of the Seventh All-Ukrainian Scientific and Theoretical Internet Conference (Lviv City, May 25, 2018) / Scientific Internet conference. - Issue 7 / Terliuk I.Ya. (compiler) / MES of Ukraine, INPP NU "Lviv Polytechnic". Lviv: Liha-Pres. Pp. 3-6.

Chechulina, A. (2020). The concept of judicial law: Russian context. Amazonia Investiga, 9(25), 223-229. Retrieved from https://amazoniainvestiga.info/index.php/amazo nia/article/view/1061/.

Criminal Procedural Code of Ukraine (2012). Verkhovna Rada of Ukraine, Ukrania, dated from April 13, 2012 No. 4651-VI. Retrieved from: https://zakon.rada.gov.ua/laws/show/4651-17. Criminal Procedural Code of Ukraine (2013). Scientific and practical commentary. Kharkiv: Odissei, 2013. 1104 p.

Decree of the President of Ukraine (2015). On the Strategy of Sustainable Development "Ukraine-2020. Verkhovna Rada of Ukraine, Ukrania, dated from January 12, 2015 No. 5/2015. Retrieved from: http://zakon3.rada.gov.ua/laws/show/5/2015.

High Council of Justice. (2019). On Approval of Amendments to the Regulations on the Judicial Protection Service. High Council of Justice, dated from December 3, 2019 No. 3300/0/15-19. https://hcj.gov.ua/doc/doc/1035.
Kuzmenko, V. A. (2013). Removal as a Measure of Procedural Coercion within Administrative Proceedings. University Sciences Notes. No. 4. Pp. 348-359.

Law of Ukraine, On the Judiciary and the Status of Judges (2016). Verkhovna Rada of Ukraine, Ukrania, dated from June 2, 2016 No. 1402-VIII. Retrieved from: https://zakon.rada.gov.ua/laws/show/1402-19. McKeever, G. (2020). Barriers to Participation for Litigants in Person in Remote Court Hearings. SSRN. Retrieved from: https://ssrn.com/abstract=3609885 or http://dx.doi.org/10.2139/ssrn.3609885.

Ngari, A., Olojo, A. (2020). Besieged but not relenting. Ensuring fair trials for Nigeria's terrorism suspects. West Africa report 29. Retrieved from https://issafrica.org/research/west-africareport/besieged-but-not-relenting-ensuring-fairtrials-for-nigerias-terrorism-suspects.

Panchenko, O. (2008). Peculiarities of the Application of Measures of Procedural Coercion in Administrative Courts by the Presiding Judge while the Court Hearings. Law of Ukraine. No. 10. Pp. 31-37.

Pylypchuk, O. O. (2018). Origin and Development of Law in the Ancient Rome (middle VIII - VI centuries B.C.). History of science and technology. Vol. 8. Issue 1. Pp. 179-190.

Shabalin, A. (2010). Features of the Formation and Development of the Institution of Injunctive Proceedings in European Procedural Law. Law of Ukraine. No. 12. P. 338.

Silviu-Ștefan, P. (2019). Some Aspects of the Right to a Fair Trial from the Perspective of the European Convention on Human Rights. Published by: Scientia Moralitas Research Institute. Retrieved from https://www.ceeol.com/search/chapterdetail?id=820107.

Tatsii, V. Ya., Hroshevyi, Yu. M., Kaplina, O. V., Shylo, O. H. (2013). Criminal Procedure: textbook. Kharkiv: Pravo. 824 p.

Tykhomyrov, Yu.A. (1996). Course of Comparative Jurisprudence. M.: Norma. 432 p. Vatamaniuk, L. (2018). National Legislation on the Judicial System and the Status of Judges: The Problem of Practical Implementation of International Standards. Judicial System in Ukraine and other countries: history and modernity (aspects of law): Materials of the Seventh All-Ukrainian Scientific and Theoretical Internet Conference (Lviv City, May 25, 2018) / Scientific Internet conference. - Issue 7 / Terliuk I.Ya. (compiler) / Ministry of Education and Science of Ukraine, INPP NU "Lviv Polytechnic”. Lviv: Liha-Pres. Pp. 17-21. 